\title{
Anti-Terrorism Legal Framework in Pakistan and Challenges before the Criminal Justice System
}

\author{
Dr. Muhammad Imran \\ College of Law, \\ Government College University \\ Faisalabad - Pakistan \\ m.imran163.adv@gmail.com \\ $\&$ \\ Dr. Rao Qasim Idrees \\ School of Law, \\ University of Gujrat, Pakistan \\ gasim.rao@uog.edu.pk
}

\begin{abstract}
Terrorism is a global problem and it is becoming more complicated over the years. Most countries including Pakistan are adopting new measures to combat terrorism. However, the existing legal regime in Pakistan has several weaknesses and the government faces new challenges in fighting terrorism. This paper examines the anti-terrorism legislation of Pakistan by arguing that it has become unsuccessful to curb the threat of terrorism by fetching the terrorists to justice. This paper also provides analysis of the development of anti-terrorism laws in Pakistan after the September 2001 terrorist attacks in the US (9/11 attacks) through a broad history of progression as per the varying nature of the hazards faced by the State. Several governments made various legal mechanisms to cope with the criminalities those could not be sought under the ordinary judicial system of the State. Being the primary anti-terrorism legislation, the Anti-Terrorism Act, 1997 is used to handle the menace of sectarian violence in the State. Due to the 9/11 attack, throughout varying character

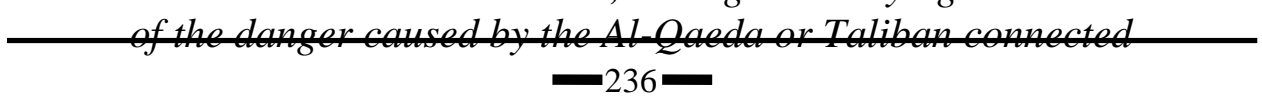


local terrorist Jihadi as well as sectarian organizations, Pakistan needs to amend not just the anti-terrorism procedure, but also required to introduce new related regulations to make the law more effective to aid speedy trials of the involved terrorists. This paper reviews critically the existing anti-terrorism laws, investigation techniques and trial processes adopted in Pakistan and identifies weaknesses and challenges in ensuring the effective implementation of the laws.

Keywords: Anti-Terrorism laws in Pakistan; Criminal Justice System; Human Rights; International Security; United Nations

\section{Introduction}

Terrorism is noticeably a global concern, and over time, it will continue to evolve through various radical groups and organisations. Globally, especially in developed countries, many countries are nowadays adopting new methods to combat crimes like terrorism through novel criminal investigation techniques. (Chaudhry, 2014) states that terrorism is a global phenomenon that does not belongs to any specific religion and knows no boundaries. Terrorism affects the region in different ways e.g. political tussles, national freedom movements, tribal conflicts, religious conflicts and ethnicity. The term terrorism has no specific definition because it often refers to the various acts of violence in the society which may cause to spread horror in the State that are not firmly in the realm of terrorism. (Deflem, 2006) asserts that it has become a matter of governmental as well as scholarly struggle to reach some precise definition of terrorism; this term is contemptuous because politically opposed parties can label their opponent's activities with it. However, basic components of a definition appear simply to take in the use or threat of violence, political stimulus and making emotional stress for some specific purpose. This term is deeprooted in the history of mankind but it has assumed new dimensions and shocking ratios with the dawn of the twenty first century. Therefore, it has engrossed key importance and attention both nationally and internationally. 
United Nations has spent significant time to make available a standard definition of terrorism which is necessary to stop and penalize different acts of terrorism. However, international community has not got success to attain a standard definition of terrorism for various reasons. There are several complications of understanding because during certain circumstances the freedom fighter of one country is a terrorist for the other country. Hence, some doubts are arising from the present drive against terrorism. (Kumar, 2012) informs that after 9 September 2001, the concern of battling with global terrorism has turn into the key objective of the global community. Terrorism is the biggest evil of the present times and affects the poor or developing countries greatly by slowing down their already lingering momentum or rhythm of development.

(Michael, 2007) argues that Pakistan is one of the most affected countries and facing terrorism on a constant basis since 1990 after the end of Afghan war in the form of prejudiced killings. (Looney, 2004) confirms that in the past 15 years in Pakistan more than 80,000 people have been killed due to terrorist acts and the national economy has suffered losses of billions of dollars and its society has been facing huge trauma. (Gunaratna, 2008) further states that on 20 September 2008, a suicide bomber in a vehicle loaded with around $800 \mathrm{~kg}$ explosives exploded himself up at the entrance of the Marriott Hotel Islamabad in which 54 people were killed and 250 were injured. A thorough police investigation resulted in arrest of four suspects, however, on 5th May 2010, Anti -Terrorist Court acquitted all four suspects due to the absence of admissible evidence. This release is a matter of serious concern as large-scale acquittals of accused terrorists by courts are alarming, revealing a severe systemic flaw in the criminal justice system of Pakistan, especially in dealing with terrorism cases. (Bokhari, 2013, p.40-41) highlights that in 2010, a report of the United States State Department described that Pakistan's anti-terrorism justice system is practically unable to prosecute suspected terrorists. (Parvez, 2015) explores the situation that horribly low conviction rate of Pakistan form the perception that even if terrorists are apprehended, the possibility to punish them is very low. 
The anti-terrorism legislation of Pakistan has continuously been reviewed by previous governments to combat against the danger of terrorism efficiently. However, due to various weaknesses within the existing antiterrorism laws, the target of complete eradication of terrorism in Pakistan has not been achieved. There are numerous shortcomings which are related to constitutional and legal drawbacks, security-related flaws, human rights violations and institutional weaknesses within the antiterrorism laws in Pakistan.

According to the Prosecutor General of the Punjab, in 2014 Anti-Terrorist Courts had heard 785 cases of terrorism in Punjab in which 196 were convicted and approximately $75 \%$ were acquitted, and this ratio is also verified in the report of United States State Department. (Erum, 2010) confirms that overloading of the criminal justice system and Anti-Terrorist Courts leads to unusual long duration of time taken by the police to investigate and followed with, trial and completion of terrorism cases by Anti-Terrorist Courts. Delay in justice will not only reduce the effect of the punishment but may also lead to revocation of testimonies by witness which give rise to a large number of acquittals. The challenges regarding countering terrorism within the criminal justice system of Pakistan are ranging from policing to inefficient prisons and also inadequate antiterrorism legislation.

\section{Research Methodology and Framework}

The current research adopts doctrinal qualitative method by analyzing the data through interpretive, evaluative and analytical approaches and that recognizes the importance of locating the research within particular social, cultural, legal and historical contexts under the light of relevant statutes of criminal law and procedural codes used in the criminal justice system in Pakistan. During the course of this research, primary sources such as case laws, books, journal articles and other relevant research materials are referred. Secondary sources of information such as research papers, magazines and electronic media are also examined. 
This study finds out first the legislation available for anti terrorism laws in Pakistan and the effectiveness with in the country. Secondly, it goes further with highlighting the lacuna and issues with available legislation. Thirdly, through available literature, this research points out the impacts of terrorism on society and lastly provides the recommendations and suggestions to mitigate the terrorism issues in Pakistan. This research finds out that terrorism is a real threat to the lives of the people and economy of the country and with introducing strong anti-terrorism laws and empowering judicial system, the terrorism in the country could be defeated.

\section{Literature Review}

A comprehensive study of anti-terrorism laws in Pakistan reveals some valuable literatures which concentrate on enhancement and implementation of the laws. (Chaudhry, 2014) identifies serious gaps and lack of coordination among the working of the police, public prosecutors and the criminal justice system. A report of the international crisis group identified the flaws of the criminal justice system of Pakistan. (Noor, 2008) investigates the prominent features of laws implemented in the country by various regimes since the creation of Pakistan to suppress violent and terrorist acts. (Kennedy, 2006) after outlining in detail the development of the anti-terrorism regime also concluded that Pakistan's anti-terrorism regime has been a "complete failure". Kennedy has given a detailed study of the framework of some amendments and how the antiterrorism law system has evolved. (Bokhari, 2013, p. 40-41) has given details about Pakistan's challenges in anti-terrorism legislation and also examines several weaknesses in the criminal justice system that cause delay in the justice. (Fayyaz, 2008) emphasises that implementation of anti-terrorism laws has been an 'unfulfilled objective' and further described frameworks of the amendments presented in the law. (Hameed, 2014) identifies weak parts of Anti-Terrorism Act and attempted to play a part in the improvement of the legal regime. He has made an effort to analyze the improvement of Anti-Terrorism Act in Pakistan and tries to give solution. (Fayyaz, 2008) peripherally examines the advancement of Anti-Terrorism Act but they have not tried thorough evaluation of the 
procedures of amendments in Anti-Terrorism Act and their effects. (Zahid, 2016) critically analyses the National Action Plan (NAP) to help reconsider the counter-terrorism policy agenda in Pakistan.

This current paper expresses sufferings of Pakistani people caused by the destructive phenomenon of terrorism. It studies the counter terrorism legislation in the post 9/11 scenario and also emphasizes on the severe systematic weaknesses of the counter terrorism legislation of Pakistan in dealing with terrorist related cases those resulted in either heap of pending cases or terrorists acquittals. It aims at giving suggestions to ensure an effective anti-terrorism system to destroy the terrorist setup and bring the perpetrators to justice.

\section{Legislation on Terrorism in Pakistan after 9/11 US Attacks}

The spread of terrorism is seen as significant evil that challenges global peace. Following 2001, a new wave of terrorism has significantly affected world peace in developed and developing countries. Before this period, there were no adequate or specific arrangements in place to fight against terrorism in the criminal justice system of various countries. However, since then, it has been well recognised by global leaders that considerable legislative arrangements need to be designed and in place by the United States (US) and European countries to improve their criminal justice system. Circumstances created by the actual terrorist attacks assaults on 9/11 (September eleven attack) experienced a huge impact on the antiterrorism laws of Pakistan. Being a member State of the United Nations, it had been made mandatory for Pakistan to make sure the implementation of its anti-terrorism laws correspond with the 9/11 attacks and also to work together with the other Member States of UN to inhibit terrorism and cut down its funding. The procedural amendments in the justice system have also been neglected in the existing law in Pakistan as there is no protection for witnesses, and in many cases, it has been reported that the accused are not convicted given the non-availability and non-production of witnesses in the court. Moreover, in the cases where hardened and desperate criminals are involved, the witnesses usually become hostile towards the prosecution team. 


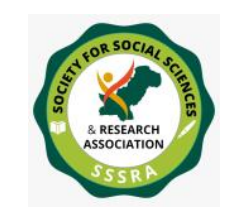

To fulfil its obligation Pakistan has introduced numerous legal procedures which involved amendments to the current Anti-Terrorism Act, 1997 and also presented various new laws to counter terrorism successfully. Firstly, the government of Pakistan increased the number of the Anti-Terrorist Courts in the State. Secondly, this presented the actual Anti-Terrorism Amendment Ordinance 2002 on thirty January 2002 with 10 months period for the fast trials from the pending matters. This Ordinance allowed Army personnel in the rank associated with Lieutenant Colonel as one of the 3 Anti-Terrorist Legal courts members on the bench to guarantee the speedy proceedings of impending cases. The actual Ordinance additionally provides stringent penalties concerning militant systems, sentencing demise penalty towards the accused individuals involved in helping and assisting terrorism. Though, it also provided right of appeal to the accused persons who is found guilty.

The presence of military officials as members in the Anti-Terrorism Courts was highly criticized by the advocates and human rights groups. As a result, new amendment was made in the Anti-Terrorism Act through Anti-Terrorism Amendment Ordinance 2002 on 16 November 2002. This amendment granted much more powers towards the police in order to counter terrorism by letting them detain the suspect for approximately twelve months without having filing any kind of criminal costs and could be released upon bail through one or more sureties to confirm his non involvement. If the suspect failed to provide sureties then he had to be presented before the court within 24 hours. (International Labour Organization, 2002).

General Pervez Musharraf presented Political Parties Order on 28 June 2002. To improve the anti-terrorism legal system; the Anti-Terrorism Act, 1997 was modified again upon 30 Nov 2004 by which two new subsections, 4-A and 4-B, were put into section 25 which supplied right associated with appeal to the actual victims as well as legal heirs, children or other loved ones of the sufferers against the choice of any kind of AntiTerrorist Courts. Government handed down Anti-Terrorism second amendment law 2004 in 11 Jan 2005, that made much more changes in the 
Anti-Terrorism Act 1997, provision of 14 years of imprisonment was replaced by imprisonment for life within Anti-Terrorism (second amendment) Act, 2004 and under its section 3 sub section (i) Special Benches of High Courts comprising of at least two judges were established for hearing the appeals of the victims or heirs of the victims. Moreover, Anti-Terrorism (second amendment) Act, 2004 allowed to transfer terrorism related cases to other provinces. This amendment also extended powers of the Anti-Terrorist Courts by allowing it to trial crimes related to kidnapping for ransom and the use of explosives. The Act also allowed the government to confiscate the passports of the criminals. (Criminal and Penal Law Pakistan, 2004, November 30).

In 2007, Prevention of Electronic Crimes Act, 2007 was promulgated and its preamble states as "to inhibit any act in contradiction to the privacy, integrity and accessibility of electronic systems, networks and data and to stop their misuse by terrorists and punishing such activities and providing mechanism for investigation, prosecution and trial of such crimes" (International Labour Organization, 2007).

Federal government of Pakistan introduced Anti-Money Laundering Laws in Sept 2007 as well as March the year 2010 to stop financing of terrorists' activities. As per Section 6 of the Ordinance, Financial Monitoring Unit was created to collect and also analyze the actual suspicious transaction reports and also to exchange the facts with appropriate investigating along with law enforcement bodies. Offences under this Ordinance are made non-bailable. Anti-Money Laundering Ordinance, 2007 lost its legal power due to the emergency imposed by General Pervez Musharraf. Therefore, in March 2010, the Parliament presented new Anti-Money Laundering Act. However, deteriorating security situation after military operation demanded more stringent laws to counter terrorism (National Counter Terrorism Authority. Amended 2016 February).

Therefore, the government presented Anti- Terrorism Amendment Ordinance in October 2009 in which new clauses were included to assist the setting up of charges against the suspected terrorists. This amendment also allowed the extrajudicial confession in front of reliable investigating 


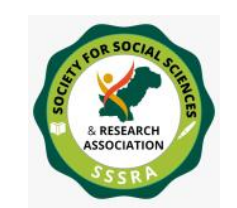

security personals in the Anti-Terrorist Courts. Furthermore, the remand duration was increased from thirty to ninety days and the government also expanded the Ordinance to the Provincially Administered Tribal Areas through a special presidential order and formed new Anti-Terrorist Courts in Khyber Pakhtoon Khawa. Definition of terrorism was also extended through an amendment and because of the deteriorating protection conditions; the federal government announced the actual regulations activity in help of municipal powers, year 2011 for Government Administered Tribal Areas as well as Provincially Given Tribal Places which permitted a legitimate framework for the Army to do procedures in Khyber Pakhtoon Khawa against terrorists. These laws also permitted the administration to establish detention centers near the Pak-Afghan border to detain persons accused of terrorism (Criminal and Penal Law, Pakistan, 1997, Anti-Terrorism Amendment Ordinance, 2009).

National Assembly of Pakistan passed the Investigation for Fair Trial Bill, 2012, on 20 December 2012, which allowed the government to access data, information or material in any documented form and also provided legal set up to the relevant agencies to conduct investigation of a suspected person's involvement in preparations for conducting an act of terrorism. However, due to increase number of terrorist incidents, Pakistan's government introduced a series of modifications in present anti-terrorism legal regime and handed down the Anti-Terrorism (Amendment) laws 2013 within March 2013 which moved the law observance agencies to consider effective steps against terrorism funding in the country. This modification also authorizes the government in order to confiscate house of anyone involved in funding terrorism; this prohibits the actual issuance associated with passport, ammunition licenses as well as credit cards to be able to militants and also prohibits the particular leaders regarding banned organizations to travel overseas. Likewise, Nationwide Assembly accepted an expenses for the development of the Countrywide Counter-Terrorism Expert (NACTA) upon 8 Mar 2013and Senate also approved it on 13 March 2013. NACTA's tasks includes “to receive and collate data or information or intelligence, and disseminate and coordinate between all relevant stakeholders to formulate threat assessments with periodical reviews to be presented to the Federal Government for making adequate 


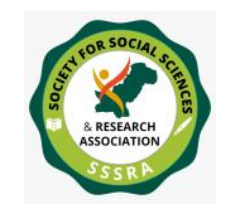

and timely efforts and to create links with the international entities for assisting in countering terrorism and extremism" (National Counterterrorism Authority, NACTA, Government of Pakistan, 2013).

The National Assembly of Pakistan set up passed the "Fair Trial Law" on $2^{\text {nd }}$ July 2014, which was introduced earlier being an Ordinance within October 2013 by the Mamnoon Hussain President of Pakistan. On $30^{\text {th }}$ June 2014, the country's senate collectively handed down the Bill also it gave much more powers in order to law enforcement institutes to fight terrorism. This labels a person as an "enemy alien" in case his identification is not recognized and found associated with conducting battle or damage and execute against Pakistan. It enables law enforcement staff of level fifteen to be able to shoot-at-sight, to look locations and to help make it non-bailable police arrest without any bring about against the suspect. Penalties of this kind of crime is up to ten years of imprisonment and it also authorizes the law observance agencies to maintain the suspect under detention for 2 months without producing him prior to the trial court and facing the particular charge of the scheduled criminal offense would have the obligation to provide proof for their innocence. The particular accused may appeal from the decision from the special court in the Higher Court. Afterwards due to the terrible terrorist assault on the APS Peshawar, typically the National Assembly of the country and the Senate accepted the twenty first Constitutional amendments Bill and also the Pakistan Army Act, 1952 Amendment on six January 2015 to form Army Courts in the country for the fast trials in the suspected terrorists. Similarly, Anti-Terrorist Courts additionally remained practical as Army courts can simply trial often the cases known by Inside Ministry. (Abdul Manan, 2014) asserts that military legal courts were prohibited in Pakistan by the Supreme Court in February 1999 but such laws would stay functional for just two years through the date of the commencement. In addition, as a result of the Army public School Peshawar incident, the federal government also raised the suspend on the performance of the demise penalty throughout terrorism-related cases. The Prevention of Electronic Crime Act, 2016 was enacted on 19 August 2016 and its preamble states as "to prevent unauthorized acts with respect to information system and provide related offences as well as mechanism for 
their investigation, prosecution, trial and international cooperation with respect thereof and for matters connected therewith or ancillary thereto" (International Labour Organization, 2016).

A summary of the anti-terrorism legislation and their objectives are presented in Table 1.1 below:

Table 1.1 Anti-terrorism Legislation and their Objectives in Pakistan

\begin{tabular}{|c|c|}
\hline Legislation / Act Name & Objectives \\
\hline $\begin{array}{l}\text { Anti-terrorism Act, } 1997 \text { (XXVII } \\
\text { OF 1997) }\end{array}$ & $\begin{array}{l}\text { To provide for the prevention of terrorism, } \\
\text { sectarian violence and the speedy trial of heinous } \\
\text { offences. }\end{array}$ \\
\hline $\begin{array}{l}\text { Anti-Terrorism (Amendment) } \\
\text { Ordinance XXXIX Of } 2001\end{array}$ & $\begin{array}{l}\text { To ban any militant or sectarian organisation and } \\
\text { also freeze their assets if found involved in } \\
\text { terrorism or terrorist activities in the State. }\end{array}$ \\
\hline $\begin{array}{l}\text { Anti-Terrorism (Amendment) } \\
\text { Ordinance VI of } 2002\end{array}$ & For the speedy trials of the pending cases. \\
\hline $\begin{array}{l}\text { Anti-Terrorism (Amendment) } \\
\text { Ordinance CXXV of } 2002\end{array}$ & $\begin{array}{l}\text { Ten months tenure for the speedy trials of the } \\
\text { pending cases. }\end{array}$ \\
\hline $\begin{array}{l}\text { Anti-Terrorism (Amendment) } \\
\text { Ordinance CXXXIV of } 2002 .\end{array}$ & $\begin{array}{l}\text { Several new clauses were included in the Anti- } \\
\text { Terrorism Act, 1997. This amendment granted } \\
\text { further powers to the police to encounter terrorism } \\
\text { by allowing them to keep a suspect for up to twelve } \\
\text { months without filing any criminal charges. }\end{array}$ \\
\hline $\begin{array}{l}\text { Anti-Terrorism (Amendment) Act } \\
\text { X of } 2004\end{array}$ & $\begin{array}{l}\text { In Section } 25 \text { after subsection (4), subsections } 4 \text { a } \& \\
4 \text { b included: } \\
\text { Any person who is a victim or legal heir of the } \\
\text { victim and is aggrieved by order of acquittal passed } \\
\text { by the Anti-Terrorism Court, may, within } 30 \text { days, } \\
\text { file an appeal in a High Court against such order. }\end{array}$ \\
\hline $\begin{array}{l}\text { Anti-Terrorism } \quad \text { (Second } \\
\text { Amendment) Act } 2004 \text { (Act II of } \\
\text { 2005) }\end{array}$ & $\begin{array}{l}\text { In Section 6, subsection (2) after clause (e) the } \\
\text { following clause shall be inserted: "(e) involves the } \\
\text { use of explosives by any device including a bomb } \\
\text { blast. } \\
\text { Section: } 7 \text { "(i), (ii), (iii), (iv), (v), (vi) and (vii); the } \\
\text { Punishments were enhanced. }\end{array}$ \\
\hline
\end{tabular}




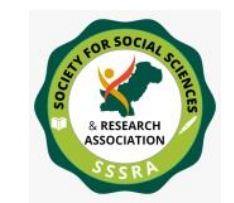

Anti Terrorism Legal Framework

\begin{tabular}{|c|c|}
\hline Legislation / Act Name & Objectives \\
\hline $\begin{array}{ll}\text { Anti-Money } & \text { Laundering } \\
\text { Ordinance, } 2007 & \end{array}$ & $\begin{array}{l}\text { To provide for the prevention of money laundering } \\
\text { and forfeiture of property derived from, or involved } \\
\text { in, money laundering and for matters connected } \\
\text { therewith or incidental thereto. }\end{array}$ \\
\hline $\begin{array}{l}\text { The Prevention of Electronic } \\
\text { Crime Act, } 2007\end{array}$ & $\begin{array}{l}\text { To inhibit any act in contradiction of the privacy, } \\
\text { integrity and accessibility of electronic systems, } \\
\text { networks and data and to stop their misuse by } \\
\text { punishing such activities. Providing a mechanism } \\
\text { for investigation, prosecution and trial of such } \\
\text { crimes. }\end{array}$ \\
\hline $\begin{array}{l}\text { Anti-Terrorism (Amendment) } \\
\text { Ordinance XXI Of } 2009 .\end{array}$ & $\begin{array}{l}\text { In the aftermath of the Lal Masjid incident, the } \\
\text { definition of terrorism was expanded by including } \\
\text { an attack on government premises, official } \\
\text { installations, schools, hospitals and other public } \\
\text { property. }\end{array}$ \\
\hline $\begin{array}{l}\text { Anti-Money Laundering Act, } \\
2010\end{array}$ & $\begin{array}{l}\text { To provide for the prevention of money laundering } \\
\text { and forfeiture of property derived from or involved } \\
\text { in money laundering and for matters connected } \\
\text { therewith or incidental thereto. }\end{array}$ \\
\hline $\begin{array}{l}\text { Anti-Terrorism (Amendment) } \\
\text { Ordinance I of } 2010\end{array}$ & $\begin{array}{l}\text { Repealed in view of Article } 89 \text { of the Constitution } \\
\text { of Islamic Republic of Pakistan, } 1973 \text { as the Anti- } \\
\text { Terrorism life of this Ordinance was } 120 \text { Days. }\end{array}$ \\
\hline $\begin{array}{l}\text { Anti-Terrorism } \quad \text { (Amendment) } \\
\text { Act, } 2013\end{array}$ & $\begin{array}{l}\text { To ban any militant or sectarian organisation and } \\
\text { also freeze their assets if found involved in } \\
\text { terrorism or terrorist activities in the State. }\end{array}$ \\
\hline $\begin{array}{l}\text { Protection of Pakistan Ordinance, } \\
2013\end{array}$ & $\begin{array}{l}\text { For protection against waging of war or } \\
\text { insurrection against Pakistan and the prevention of } \\
\text { acts threatening the security of Pakistan. }\end{array}$ \\
\hline $\begin{array}{lcc}\text { National Counter } & \text { Terrorism } \\
\text { Authority } & \text { Act, } 2013 & \end{array}$ & $\begin{array}{l}\text { To curb the menace of terrorism to receive, collate } \\
\text { data, information and intelligence disseminate and } \\
\text { coordinate between all relevant stakeholders to } \\
\text { formulate a threat assessment with periodical } \\
\text { reviews to be presented to the federal government } \\
\text { for making an adequate and timely effort to counter } \\
\text { terrorism and extremism }\end{array}$ \\
\hline
\end{tabular}




\begin{tabular}{|l|l|}
\hline \multicolumn{1}{|c|}{ Legislation / Act Name } & \multicolumn{1}{|c|}{ Objectives } \\
\hline $\begin{array}{l}\text { Anti-Terrorism } \\
\text { Amendment) Act, 2014 }\end{array}$ & $\begin{array}{l}\text { To address the shortcomings relating to the } \\
\text { terrorism financing provisions in the Anti- } \\
\text { Terrorism Act, 1997, covering all aspects of the } \\
\text { offence in light of international standard and to } \\
\text { provide for more effective measures for law } \\
\text { enforcement agencies to investigate the offences. }\end{array}$ \\
\hline Protection of Pakistan Act, 2014 & $\begin{array}{l}\text { For protection the against waging of war or } \\
\text { insurrection against Pakistan and the prevention of } \\
\text { acts threatening the security of Pakistan and for } \\
\text { speedy trial of the offences falling in the schedule } \\
\text { and for matters connected therewith or incidental } \\
\text { thereto. }\end{array}$ \\
\hline $\begin{array}{l}\text { The Prevention of Electronic } \\
\text { Crime Act, 2016 }\end{array}$ & $\begin{array}{l}\text { To prevent unauthorised acts with respect to the } \\
\text { information systems and provide related offences } \\
\text { as well as a mechanism for their investigation, } \\
\text { prosecution, trial and international cooperation with } \\
\text { respect thereof and for matters connected therewith } \\
\text { or ancillary thereto. }\end{array}$ \\
\hline
\end{tabular}

Source: Developed by Authors from Analysis of Anti-Terrorism

Legislations in Pakistan.

\section{The Lacunas to Counter Terrorism in Pakistan}

\subsection{Constitutional and Legal Lacunas}

There are numerous legal as well as constitutional lacunas in the antiterrorism laws associated with Pakistan and made the anti-terrorism laws less efficient to convict individual terrorists or terrorist groups. The lacunas are as follows:

i. A broad definition of terrorism in ATA is the major weakness in the anti-terrorism legal framework in Pakistan which has placed a considerable burden on ATCs because they need to try such crimes which can be tried by ordinary courts. This has resulted in the 
accumulation of pending cases and also has slowed the process of prosecuting high profile terrorists.

ii. Implementation of anti-terrorism laws in FATA is another drawback of the anti-terrorism legislation of Pakistan. This is because these laws do not legitimately apply to terrorists from FATA, even though they are arrested from the settled parts of the State. They have to be sent to their respective agency and could instead be tried under the Frontier Crimes Regulation 1872 (FCR). However, the militants arrested during military operations should be moved from the location of the crime scene and placed under police custody for investigation. However, this situation gives rise to a further difficulty as the suspected terrorist was not arrested by the Police, who have not made the Police report, nor visited the crime scene. It depends upon the evidence presented by the military officials. This weakens the case when the State prosecutor files the challenge in the court against the detained militant. As a result, the alleged terrorist could escape easily without being convicted or obtain bail before the decision of the trial.

As mentioned in this study, terrorism has become a constant threat for Pakistan for the past few decades and has become an existential threat. In order to curb this current wave of terrorism, Pakistan has presented ATA, 1997, POPA, 2014 and NACTA, 2013. The ATA was formed for speedy trials of heinous crimes but due to its stringent laws and extra powers given to the armed officers; ATA bears severe criticism as it can be misused. Section 3(2)(a) of ATA provides an officer of BS 15 or armed forces or civil armed forces the right to shoot on sight powers which are a violation of human rights. Section 10 of ATA 1997 also authorised the police, armed forces or civil armed forces to enter/search in any premises without a warrant in case of suspicion. If any suspect is arrested, then the investigation would be completed within one week, and ATC trials would take no longer than seven working days. Given this short period, it could not be a fair trial and a violation of international standards. 
(Iftikhar, 2014) suggests that in order to tackle and address the emanating threat of terrorist attacks the government of Pakistan has presented POPA, 2014 in order to provide " protection against the waging of war or insurrection against Pakistan" but due to the presence of several weaknesses as discussed in the earlier subheading it is highly criticised by human rights activists, community of advocates and members of the national assembly who have referred to this law as 'draconian' due to its strict laws, punishments and massive powers awarded to law enforcement agencies which violate Article 10-A of the Constitution of Pakistan, 1973. POPA, 2014 does not explain the criteria of an 'enemy alien'. Therefore, when an accused is presented to the court, he or she is cleared and released because of the absence of the criteria of an enemy alien. Therefore, due to several reasons, controversies and criticism by human rights organisations, the government was reluctant to proceed in implementing it as it overlaps with ATA, 1997 and only thirty cases were registered under this Act as shown in Table 1.2.

Table 1.2 Protection of Pakistan Act, 2014 offences overlaps with AntiTerrorism Act, 1997

\begin{tabular}{|l|l|l|}
\hline $\begin{array}{l}\text { S. } \\
\text { No. }\end{array}$ & Types of offences under POPA, 2014 & Overlaps with ATA, 1997 \\
\hline 1 & $\begin{array}{l}\text { Crimes against religious, ethnic and } \\
\text { political groups or minorities. }\end{array}$ & $\begin{array}{l}\text { Already part of scheduled offences } \\
\text { since 1997. }\end{array}$ \\
\hline 2 & $\begin{array}{l}\text { Arson, use of firebombs, suicide } \\
\text { bombs on the public, government } \\
\text { premises, sites of worship, historical } \\
\text { places and attacks against citizens. }\end{array}$ & $\begin{array}{l}\text { Incorporated in between ATA 2002 } \\
\text { and 2005. }\end{array}$ \\
\hline 3 & $\begin{array}{l}\text { Murder, kidnapping, extortion of } \\
\text { government and private persons or } \\
\text { public figures. }\end{array}$ & $\begin{array}{l}\text { Already part of scheduled offences } \\
\text { since 1997. }\end{array}$ \\
\hline 4 & $\begin{array}{l}\text { The attack on public or private } \\
\text { property. }\end{array}$ & $\begin{array}{l}\text { Already part of scheduled offences } \\
\text { since 1997. }\end{array}$ \\
\hline 5 & $\begin{array}{l}\text { Sabotage of communication lines, grid } \\
\text { stations, energy facilities, airports, } \\
\text { educational institutions, police stations } \\
\text { and mass transport systems. }\end{array}$ & $\begin{array}{l}\text { Incorporated in the ATA between } \\
\text { 2000 and 2003. }\end{array}$ \\
\hline
\end{tabular}


"One of the reasons for only a few cases registered under POPA". Source: Developed by Authors by Analysing the Protection of Pakistan Act, 2014 and Pakistan's Anti-Terrorism Act, 1997.

Section 15(1) of POPA stated that "an enemy alien or a militant facing the charge of a scheduled offence, shall be presumed to be engaged in waging war or insurrection against Pakistan unless he establishes his noninvolvement in the offence". Under the POPA, the State has the right to detain, and intern without disclosure of the grounds for detention and internment has been regulated through Section 6 of the POPA that contradict with Article 10-A of the Constitution of the Pakistan that provides safeguard against illegal arrest and detention of citizens (National Assembly Of Pakistan, 2014).

(Zahid, 2016) informs that the NACTA was established in 2008, but due to the many hurdles and conflicting tussles between the civilian government and Pakistani military to gain control of The National Counter Terrorism Ordinance, after the delay of several years since its formation, it was finally implemented in 2013.

(Zafar, 2015) states that NACTA launched the National Internal Security Policy (NISP) in May 2014 for Madrasah reforms to enhance the capability of law enforcement forces, improvement of an anti-terrorist force at the national level, to cut terrorist financing, and for the return and registration of Afghan refugees. However, the NISP failed to give the desired results given its delay in the implementation which was due to the requirement of massive funds, i.e. USD 305 Million. After APS in the Peshawar incident on 16 December 2014 in which 132 children were brutally martyred, the government of Pakistan introduced a new counterterrorism policy called NAP. (Mateen, 2014) argues that although, the NAP is not a comprehensive or proper counter-terrorism policy yet it has attained mixed results. The NAP is praised by the government and the citizens of Pakistan except for the Islamic political parties who objected in using the word "religion" in the text regarding the trial of persons in Military Courts of terrorist organisations. One of the reasons for its poor 
success is due to its implantation in fragments. (Rashid, 2016) explains that the government was unwilling to implement NAP, but following the APS incident, based on immense public pressure, a few parts of its policies were implemented in true spirit. However, several terrorist organisations started reappearing under new names.

\subsection{Security Related Weaknesses}

The legal regime with respect to terrorism has failed to ensure the security of judges, witnesses and prosecutors alike. There are numerous cases where witnesses had not appeared before the courts because of security threats as seen in the case of Munir Ahmad $v$ The State case, where the eyewitness was killed before the trial was started, and the case ended in an acquittal. Consequently, militants were either acquitted or their trials were postponed due to lack of evidence (The Pakistan Code, 2014). It can also be seen in the case of "Wali Khan Babar", a reporter of the private TV channel in January 2011. (Committee to Protect Journalist. (2014, March 2) informs that during the court's proceedings, 6 witnesses and 1 prosecutor had been killed and the Sindh federal government shifted the case from the Karachi High Court to the ATC in Nov 2013. The ATC found guilty 4 individuals and sentenced them to life imprisonment, and the some other 2 accused received death penalties in absentia". (Sherazi, 2013, August 13) analyses which, being scared of the serious reaction through the terrorist organizations, the government by itself was hesitating to enforce the demise sentence within the criminals based on the judgments from the ATCs. (Craig \& Morello, 2015, January 13) states that this government raised the suspend on the dying penalty following the APS Peshawar incident keep away from 2014 where several terrorists have been hanged.

\subsection{Human Rights Violations}

There are several issues associated with human legal rights violations within the anti-terrorism laws in Pakistan as follows.

i. (Human Right Watch 2014, July 21) asserts that based on human legal rights activists, the actual anti-terrorism regulations of 
Pakistan violate the essential of the suspect's innocence till proven responsible. For example, because of a modification in ATA made in this year, the person has to confirm his innocence before the court concerned. Otherwise, he will be declared guilty, and it would make him responsible for being tried under the laws of the ATA. In this case, (Sahito, 2009) argues that "due to the defective investigation process and the corruption in the Police department that still depends on witness reports for evidence; one may not reject misuse of the law and it heightens the chances of victimisation of the suspect".

ii. A human rights activist, for instance, Human Rights Watch and the National Commission for Human Rights claim that the Extrajudicial confessions clause of 2009 (amendment) in the ATA authorises investigation officials to torture suspects, and security personnel can record extrajudicial confessions and present as evidence to the ATCs. Moreover, it provides extra powers to security agencies for treating the suspects using extrajudicial means without being ultimately held accountable. Additionally, the prescribed 7 days' time limit of completion of the trial forces the investigation officers (IOs) to alter the evidence and use violent techniques on suspects. In addition, these regulations have been taken advantage of by the law enforcement and protection agencies to be able to detain suspects illegally without having presenting all of them before the legal courts (National CommissionforHumanRights,2017).

iii. The ATA and ATCs were set up due to the failure of the court system of Pakistan in providing speedy disposal of cases. However, the actual ATCs additionally remained weak against politics influence and for that reason violating fundamental human rights. (Dawn, 2008, May 10) states which in the case of Sardar Akhtar Mengal, the former leader of the Baluchistan National Party, the ATC-V of Karachi declared his act as criminal for making a few Army staff hostage. Having been arrested within September 2006 and continued to be in unlawful custody till his release in 2008 through the government of Pakistan Peoples Party out the case 
through section 494 of the Cr. P. C. Similarly, Nawaz Sharif became the particular victim associated with his own developed ATA. Individual rights organizations criticise typically the ATCs insufficient independence since the judges of those courts tend to be answerable towards the executive as its release in 1997 the ATA has been utilized by the various authorities for political victimisation of the political competitors. A judge of ATC Karachi, Syed Hassan Shah Bokhari stated, "Until the democratic federal government was selected in Feb 2008, the majority of ATCs had sentenced many people in jail through instructions, instead of on the basis of free and fair trials".

iv. The POPA provides Law enforcement officers authority in order to "shoot-on-sight", that increased often the concerns in the misuse by providing the Police any "legal certification to kill" suspects, especially in extra-judicial cases. The police department in Pakistan has an ignoble record regarding extra-judicial killings, and this take action would offer only a legal protection to this kind of killings.

\subsection{Institutional Lacunas}

The main institutional weakness in the anti-terrorism legislation are as follows.

i. The lack of a powerful mechanism to be able to enforce the exact ban around the illegal extremist groups which have reappeared with different names. The actual banned Lashkar-e-Taiba reemerged with the new title of the Jama'at-Ud-Dawa and the Sipahe-Sahaba in Pakistan, re-emerged right after its suspend in 2002, named Millat-i-Islamia Pakistan, that was again prohibited in the year 2003. However, the very group once more reappeared since the Ahl-e-Sunnat Wal-Jama'at, but again had been outlawed in 2012 (Muhammad Ali,2017).

ii. The particular deficiency of financial situation and personnel has also considerably affected the significant environments in the 
ATCs. Even though role involving ATCs is placed as a similar system with normal courts, state prosecutors hired from the ATCs are not able to use the sources available to the routine sessions courts (Tanoli, 2016).

Accordingly, it has also led to increasing the main workload on the ATCs and also the delay within the trials connected with suspected terrorists. (Hashim, 2015 January 11) argues that currently, a lot more than 17,000 cases are under trial at ATCs in Pakistan, and based on the Supreme Court of Pakistan eighty-five \% of those aren't associated to help terrorism; for instance kidnapping with regard to ransom, killing and narcotics trafficking. This highlights the actual inefficacy within the anti-terrorism program, under which a terrorist suspect cannot be legally detained for more than two months, and thus, they are appropriately released.

iii. Another main institutional weakness in the anti-terrorism laws is a result of the lack of sharing of information amongst significant agencies of the country. Furthermore, Ex ISI director, General Ahmed Shuja Pasha said that there is certainly lack of coordination between numerous intelligence agencies in Pakistan, for instance, the particular Military agencies i.e., Naval agencies, Air Force agencies, Intelligence Agency, the Legal Investigation Division and the special branch regarding sharing data on cases relevant to terrorism.

\section{Conclusion}

Pakistan develops a number of anti-terrorism legislations, which have started like a national system in order to fight sectarian physical violence and governmental opponents recognizing the local and worldwide responsibilities following the 9/11 attacks intended for encountering the very menace with terrorism dedicated by the local Jihadi and also sectarian categories that have close connections along with Al-Qaeda and Taliban. Even though several government authorities have introduced various strict 
laws towards counter terrorism especially after $9 / 11$, however they have turned out to be less effective to prevent the occurrence of terrorism which has been continuously happening in Pakistan.

Summarily, the primary aim of anti-terrorism legislations for Pakistan would be to deter terrorism by giving the fast delivery about justice via Anti-Terrorist courts and also Army courts. However, these targets are yet to be accomplished. Due to the broad and extended definition of "terrorism" in the Anti-Terrorism Act, the main Anti-Terrorist courts which are currently facing issues of much less staff in addition to funding are generally overloaded together with terrorism situations. In addition, the actual widespread data corruption in the police force department; faulty investigations plus trial methods; and the not enough adequate safety for witnesses, judges and even prosecutors possess resulted in higher acquittal rate. Besides this particular, anti-terrorism laws and regulations of Pakistan are also dealing with criticism significantly by human rights activists due to the misuse of these rules by giving extra-judicial powers for the Police together with security organizations. According to the activists the law require to complete the trial in seven days, provides a license to the Police to get using cruel methods of punishments and torture against the suspects in their custodianship without any responsibility.

Additionally, the "Protection of Pakistan Act" permits law enforcing agencies to maintain the terrorists who had been detained throughout the military procedures in their legal care for up to 60 days. It is the sole obligation of the State to stop forced disappearance of suspects which creates conflict between anti-terrorism laws and the safeguard of the basic human rights. While the legal means to prosecute and punish terrorists have extended in recent years, it is crucial to ensure an effective antiterrorism system. Such effective system needs to address the abovementioned weaknesses in the existing anti-terrorism legislations of the country in curbing the terrorist activities and for bringing the perpetrators to justice. It is argued that the anti-terrorism laws have to be implemented in combination with the strong and stable political, security, and administrative aspects for a holistic approach to counter the menace of 
terrorism. In conclusion, an adequate anti-terrorism laws and effective implementation is extremely imperative in countering terrorism. 


\section{REFERENCES}

Bhutta, Z. (2015, August 3). New Policy to Guide Afghan Repatriation Till 2015. The Express Tribune.

https://tribune.com.pk/story/586277/new-policy-to-guide-afghanrepatriation-till-2015.

Bokhari, S. W. (2013). Pakistan's Challenges in Anti-terror Legislation. Center for Research and Security Studies.

Chaudhry, R. (2014). Anti-Terror Laws, Policing and the Criminal Justice System: Anti-Terrorist Efforts in Punjab. Lahore: Centre for Public Policy and Governance.

Committee to Protect Journalist. (2014, March 2). In Pakistan, six convicted in Wali Khan Babar murder. https://cpj.org/2014/03/inpakistan-six-convicted-in-wali-khan-babar-murde/.

Craig, T \& Morello, C. (2015, January 13). Pakistan Hangs Seven to Show Determination to Fight Terrorism. The Washington Post.

https://www.washingtonpost.com/world/pakistan-hangs-seven-toshow-determination-to-fight-terrorism/2015/01/13/61a71066-9b1311e4-bcfb-059ec7a93ddc_story.html

Criminal and Penal Law Pakistan. (2004, November 30). Anti-Terrorism (Amendment) Act, 2004 (No. X of 2004).

https://www.ilo.org/dyn/natlex/natlex4.detail?p_isn=86210\&p_lang=

Criminal and Penal Law, Pakistan. (1997). Anti-Terrorism Act, 1997

(No. XXVII of 1997). Amendment Ordinance, 2009.

https://www.ilo.org/dyn/natlex/natlex4.detail?p_lang=\&p_isn=81777\& p_classification $=01.04$

Dawn (2008, May 10). Mengal Freed: Worried About Missing Workers. Dawn News. https://www.dawn.com/news/302159/mengal-freedworried-about-missing-workers. 
Deflem, M. (2006). Europol and The Policing of International Terrorism: Counter-terrorism in a global perspective. Justice Quarterly, 23(3), 336-359.

Fayyaz, S. (2008). Responding to terrorism: Pakistan's anti-terrorism laws. Perspectives on Terrorism, 2(6), 10-19. https://www.jstor.org/stable/26298353?seq=1\#metadata_info_tab_con tents.

Gunaratna, R. (2008). The Islamabad Marriott in Flames: The Attack on the World's Most Protected Hotel. Journal of Policing, Intelligence and Counter Terrorism, 3(2), 99-116.

Haider, M. (2014, December 30). Military Courts Parts of National Action Plan: PM Nawaz. Dawn News. https://www.dawn.com/news/1154046.

Hameed, H., \& Jamshed, M. (2013). A Study of The Criminal Law \& Prosecution System in Pakistan. J: Manzil Pakistan.

Hashim, A. (2015, January 11). Army Courts to try Pakistan Terror Suspects. Al Jazeera.

https://www.aljazeera.com/features/2015/1/11/army-courts-to-trypakistan-terror-suspects.

Human Right Watch (2014, July 21). Pakistan's Dangerous Anti-terrorism Law. The Tribune. https://www.hrw.org/news/2014/07/21/pakistansdangerous-anti-terrorism-law.

International Labour Organization. (2016). Prevention of Electronic Crime Act._Criminal and Penal Law Pakistan.

https://www.ilo.org/dyn/natlex/natlex4.detail?p_isn=104952\&p_lang= en.

International Labour Organization. (2002). Anti-Terrorism Amendment Ordinance, 2002.

https://www.ilo.org/dyn/natlex/docs/ELECTRONIC/64759/88940/F1 046432377/PAK64759.pdf. 
International Labour Organization. (2007). Prevention of Electronic Crimes Act. https://www.ilo.org/newdelhi/areasofwork/childlabour/legal-framework/WCMS_300693/lang--en/index.htm

Janjua, R. W. (2016, May 19). Whither National Action Plan? The News International. https://www.thenews.com.pk/print/121018-WhitherNational-Action-Plan.

Khan, I. A. (2014, February 4). Pakistan Protection Ordinance termed a draconian law. Dawn News. https://www.dawn.com/news/1084809.

Kumar, C. (2012). Challenges of Global Terrorism-Strategies, Dimensions and Response: In Search of a Perspective. International Affairs and Global Strategy, 3, 7-20.

Looney, R. (2004). Failed Economic Take-offs and Terrorism in Pakistan: Conceptualizing a Proper Role for US Assistance. Asian Survey, 44(6), 771-793.

Lum, C., Kennedy, L.W. and Sherley, A., (2006). Are Counter-Terrorism Strategies Effective? The Results of the Campbell Systematic Review on Counter-Terrorism Evaluation Research. Journal of Experimental Criminology, 2(4), 489-516.

Manan, A. (2014, December 18). PM lifts ban on executions in terrorism cases. The Express Tribune. https://tribune.com.pk/story/808199/pmlifts-ban-on-terrorism-cases.

Michael, S. (2007). Terrorism a Socio-Economic and Political Phenomenon with Special Reference to Pakistan. Journal of management and social sciences, 3(1), 35-46.

National Assembly Of Pakistan. (2014). Section 6, The Protection of Pakistan Act. http://www.na.gov.pk/uploads/documents/1391322775 795.pdf.

National Counter Terrorism Authority. (2016 February). Anti-Money Laundering Ordinance 2010 https:/nacta ov ply 
content/uploads/2017/08/Anti-Money-Laundering-Act-2010amended-upto-February-2016.pdf.

National Counter Terrorism Authority NACTA, (2013). Government of Pakistan http://www.nacta.gov.pk.

Nekokara, M. A. (2017, January 25). Crime of Extra-judicial Killing. New Age Islam. https://www.newageislam.com/pakistan-press/new-ageislam-edit-bureau/crime-of-extra-judicial-killing-new-age-islam-sselection-25-january-2017/d/109836.

Noor, S. (2008). Evolution of Counter-Terrorism Legislation in Pakistan. Conflict and Peace Studies, 1(1).

Parvez, T., \& Rani, M. (2015). An Appraisal of Pakistan's Anti-Terrorism Act. US Institute of Peace. https://www.usip.org/sites/default/files/SR377-An-Appraisal-ofPakistan\%E2\%80\%99s-Anti-Terrorism-Act.pdf

Sahito, I. H. (2009). The Criminal Investigation in Pakistan: Trends and Reality. Journal of Pakistan Vision, 10(2), 175-196.

Sherazi, Z.S. (2013, August 13). Punjabi Taliban Warn of Reprisal if PML-N Government Hangs Militants. Dawn. https://www.dawn.com/news/1035449

Tanoli, Q. (2016, June 8). Banned Groups Continue to Resurface Under New Names. The Express Tribune. https://tribune.com.pk/story/1118483/weak-enforcement-bannedgroups-continue-resurface-new-names.

The Pakistan Code. (2014). Section 2(f), The Protection of Pakistan Act. http://pakistancode.gov.pk/english/UY2FqaJw1-apaUY2FqaapaUY2FqZ5s\%3D-sg-jijijijijijiji.

United Nations Human Rights Treaty Bodies. (2017). Concluding observations on the initial report of Pakistan. 
https://tbinternet.ohchr.org/Treaties/CAT/Shared\%20Documents/PAK /INT_CAT_COC_PAK_27467_E.pdf.

Zahid, F. (2016). Counter Terrorism Policy Measures: A Critical Analysis of Pakistan's National Action Plan. The Mackenzie Institute, 19. 